\title{
FEES AND USER CHARGES IN PUBLIC FINANCE. EVIDENCE FROM SELECTED OECD COUNTRIES
}

\begin{abstract}
The aim of this article is to assess the importance of user charges as a source of revenues in state and local government and factors that impact a volume of these revenues. In order to carry out the research it has been assumed that volume of revenues from fees and user charges are dependent on fiscal decentralization, are positively affected public expenditure and depend on the wealth of a society. Two models - for the whole public sector and for state and local government has been designed. Using a panel of 26 selected OECD countries in period 1995-2016 it has been proved that decentralization is a significant factor only in case of fees and user charges in whole public sector but not significant in decentralized model. As expected fees and user charges positively depend on volume of expenditures in both models and additionally negatively depends on tax burden.
\end{abstract}

Keywords: fees, user charges, local budgets, tax and non-tax revenues

\section{Streszczenie}

\section{Opłaty i opłaty za usługi w finansach publicznych. Doświadczenia wybranych krajów OECD}

Celem tego artykułu jest ocena znaczenia opłat i opłat pobieranych od użytkowników jako źródła dochodów dla finansów samorządowych oraz czynników wpływających na wielkość tych dochodów. W celu przeprowadzenia badań przyjęto, że wielkość przychodów z opłat i opłat za usługi od decentralizacji fiskalnej pozytywnie wpływa na wydatki publiczne i zależy od zamożności społeczeństwa. Zaprojektowano dwa modele: dla całego sektora publicznego oraz dla władz regionalnych i lokalnych. Przy użyciu panelu dwudziestu sześciu wybranych krajów OECD w latach 1995-2016 udowodniono, że decentralizacja jest istotnym czynnikiem tylko w przypadku opłat i opłat za użytkowanie w całym sektorze publicznym, ale nie jest znacząca w modelu zdecentralizowanym. Zgodnie z oczekiwaniami opłaty i obciążenia użytkowników pozytywnie zależą od wielkości wydatków w obu modelach i dodatkowo negatywnie zależą od obciążeń podatkowych.

Słowa kluczowe: opłaty, opłaty publiczne, budżety lokalne, dochody podatkowe i niepodatkowe 


\section{Introduction}

When the traditional tax revenues of local governments appear to be insufficient for those entities to carry out tasks, they strive for other sources. The gradual depletion of revenues from the assets of local government units very frequently leads to the introduction of fees and user charges for services.

Each country, according to its preferred policy public service provision, determines diversified sources of revenue for both central government level and local government level. Commonly, there are fees for issuing a particular type of document. However, due to the fact that fees are not determined by the cost of the provision of services, they are a different instrument to a typical user charge. The term 'user charge' refers to a situation where the benefit to the beneficiary is proportional to the user charge paid and, therefore, according to the theory by Feldstein [1972], the user charge may be set at the marginal cost of providing the service.

User charges, apart from having a strict financial goal, also allow public authorities to achieve additional objectives, such as regulating the demand for services, and hence more effective allocation of resources than is the case when financing with funds from taxes. Revenues from user charges can be adjusted to bear the required costs. Assuming that a substantial part of the user charge relates to the variable part, changes in demand will result in proportional changes in both revenues and expenditure.

The aim of this article is to assess the importance of fees and user charges in the revenues of local government in selected OECD countries. The structure of the article is as follows: section 1 reviews recent research on fees and user charges in local government and section 2 presents research on fees and user charges in some selected European countries.

\section{Literature review}

The main reason for the introduction of nontax instruments by public authorities, especially local government, is the need to generate additional funds. Important sources of revenue for public funds are fees and user charges. Justification for this type of public revenue can be found in the benefit model of local government finance which assumes that local governments should, wherever possible, charge residents for the services they provide with taxes or user charges reflecting the benefits received [Bird, Slack, 1993]. The specific objective of introducing user charges is to provide self-financing or partial self-financing of the provision of certain public services. The introduction of user charges is motivated by limiting taxes and spending [Sun, Jung, 2012].

The introduction of multiple sources of public revenue leads to a situation in which it is difficult for a taxpayer to determine the actual cost of providing public services. Under this assumption, the introduction of fees and user charges aims 
therefore to provide revenues in lieu of phased out and declining tax revenues. Since fees and user charges are public levies, they are one of the critical factors of assessment in local government units [Wagner, 1976].

The difference in the use of taxes on the one hand and user charges on the other is based on the function of public finances. Public finance theory suggests that with taxes, a redistributive function is mainly implemented, and with user charges - allocative. There are also different approaches, i.e. showing that separating income tax as a purely redistributive instrument and user charges as a purely allocative instrument does not apply. Moreover, the use of "user charges" limits the redistributive functions of income tax [Bös, 1984]. Regardless of the form of payment - a tax, fee or user charge, the decision to introduce fees and user charges is political in nature, unless particular goods are supplied by a private entity [Swope, Janeba, 2005]. This follows directly from the nature of public finances, i.e. the political nature of decision-making. It also means that both the introduction of payment, as well as determining the level of payment, will be linked to the preferences of the decision-making body.

The issue of user charges and the rapid growth of their differentiation is indicated in research by Feldstein [1972], in which he emphasizes the need to answer questions on both the equity and efficiency of public spending decisions financed by fees and user charges. It should be noted, however, that in the case of equity, this refers not only to redistribution, but also to the regulation of demand with the introduction of user charges.

Research on the role of user charges in financing systems, both in local government units and at the central level, indicates that these sources of revenue are gaining importance due to the widening range of tasks carried out by public entities. The increasing importance of user charges to local government budgets is an international trend [Börge, 2000; Będzieszak, 2013]. Another reason is the nature of tax revenues, which are dependent on the economic situation. For example, in the USA, user charges for public services in recent decades have become very significant despite the continued dominance of taxes [Huber, Runkel, 2009] - a good example of this is the share of user charges in federal budget revenues in the USA, where the share of these payments increased from $8.8 \%$ (fiscal year 1976-1977) to $10.5 \%$ (fiscal year 1991-1992), and at the local level from $10.7 \%$ (fiscal year 1976-1977) to $15.3 \%$ (fiscal year 2000-2001). This trend is confirmed by the study on Swiss cantons [Feld et al., 2003]. The Author of the study also claim that, while tax revenues cannot be flexibly adjusted due to tax competition, in the case of user charges for public services this restriction is far less important. From a theoretical point of view, a factor that limits the flexibility of user charges is the transport costs which residents would have to pay if they want to take advantage of a specific service in another local government unit [Cremer et al., 1997]. In the immediate vicinity of a specific local government unit, the level of user charges for similar services should be comparable, although some studies suggest that the decentralized method of setting user charges is inefficient [Fuest, Kolmar, 2007]. But there is another, more important factor determining the level of user charges: residents' private income - a higher private income leads to 
higher user charges, which in his opinion probably reflects the increased demand for these services [Börge, 2000]. This means, therefore, that in the case of local government units with a similar level of economic development, the level of user charges should also be similar.

User charges, as a rule, cover part of the costs for providing the service, and thus it is necessary to determine what part this should be [Nallathiga, 2009]. A higher level of revenue from user charges for a service compared to expenditure for this service leads to a lower level of public spending [Bierhanzl, Downing, 1998], but also greater reliance on user charges for financing public services leads to a reduction in municipal expenditure [Sun, Jung, 2012].

Those municipalities that do not yet charge users, plan to do so in the future, and expect to increase revenues from this source by up to $400 \%$ for some services [Downing, 1992]. An alternative approach, based on the analysis of marginal costs and externalities, indicates that the total revenue from increased user charges is potentially quite significant—rising from the current 0.259 to as much as 0.848 . While the collection of revenue is an important objective of introducing or expanding the scope of user charges, it is equally important to ensure equality and efficiency [Sepehri, Chernomasa, 2001].

\section{Trends in fees and user charges in OECD countries}

Research on fees and user charges has been conducted on the panel of selected OECD countries in the period of 1995-2016.

In most countries in the analysed period, the level of public revenue in relation to GDP increased. The exceptions to this rule were mostly developed countries. The average increase in public revenue amounted to $3.79 \%$ GDP, while the average decrease was $2.85 \%$ GDP.

The most important source of public revenues is taxes. They accounted from $73 \%$ to $93 \%$ of public revenues and, despite the many changes that occurred in the economies of the countries in the period, this ratio did not change substantially. As a rule, therefore, changes in public revenues resulted from changes in tax revenue.

Table 1 and table 2 present some basic information about tax burden, fees and user charges and public expenditures (as \% GDP). The former table presents average value of indicators for each year, and the latter-for each country.

On average tax burden has not changed much, which is a consequence of opposite direction of changes in certain countries. The number of countries with increase in tax burden was 12 (average increase 3,00\% GDP), and the number of countries with decrease was 13 ( $-2,28 \%$ GDP).

The situation of countries was quite different, however, regarding revenues from fees and user charges. As with the two previous features, fluctuations can be positive or negative. However, in this case, the relation of fees and user charges to changes in tax revenues is important. As mentioned earlier, tax revenues are the most important source of public revenue. However, they are intrinsically linked 
Table 1

Time series data on tax, fees and expenditures

\begin{tabular}{|c|c|c|c|c|}
\hline Year & $\begin{array}{c}\text { Tax burden as } \\
\% \text { GDP }\end{array}$ & $\begin{array}{c}\text { Fees and user } \\
\text { charges as } \\
\% \text { GDP }\end{array}$ & $\begin{array}{c}\text { Local and re- } \\
\text { gional fees and } \\
\text { user charges as } \\
\% \text { GDP }\end{array}$ & $\begin{array}{c}\text { Share of local } \\
\text { and state taxes } \\
\text { in total taxes }\end{array}$ \\
\hline 1995 & 35.98 & 3.22 & 1.85 & 5.23 \\
\hline 1996 & 36.35 & 3.24 & 1.87 & 5.25 \\
\hline 1997 & 36.12 & 3.16 & 1.80 & 5.07 \\
\hline 1998 & 36.29 & 3.06 & 1.78 & 4.99 \\
\hline 1999 & 36.46 & 3.10 & 1.82 & 5.08 \\
\hline 2000 & 36.28 & 3.05 & 1.76 & 4.92 \\
\hline 2001 & 35.56 & 3.08 & 1.77 & 5.08 \\
\hline 2002 & 35.31 & 3.14 & 1.80 & 5.24 \\
\hline 2003 & 35.13 & 3.15 & 1.84 & 5.39 \\
\hline 2004 & 35.12 & 3.19 & 1.83 & 5.38 \\
\hline 2005 & 35.39 & 3.20 & 1.80 & 5.23 \\
\hline 2006 & 35.47 & 3.18 & 1.78 & 5.14 \\
\hline 2007 & 35.57 & 3.16 & 1.76 & 5.07 \\
\hline 2008 & 34.97 & 3.23 & 1.80 & 5.32 \\
\hline 2009 & 34.47 & 3.52 & 1.95 & 5.84 \\
\hline 2010 & 34.46 & 3.56 & 1.94 & 5.84 \\
\hline 2011 & 34.74 & 3.53 & 1.91 & 5.69 \\
\hline 2012 & 35.25 & 3.58 & 1.94 & 5.70 \\
\hline 2013 & 35.66 & 3.48 & 1.88 & 5.59 \\
\hline 2014 & 35.81 & 3.45 & 1.85 & 5.48 \\
\hline 2015 & 35.83 & 3.41 & 1.82 & 5.38 \\
\hline 2016 & 36.13 & 3.40 & 1.82 & 5.36 \\
\hline
\end{tabular}

Source: own calculations on a basis of OECD Fiscal Decentralisation Database. 
Table 2

Cross-section data on tax, fees and expenditures

\begin{tabular}{|c|c|c|c|c|}
\hline Country & $\begin{array}{c}\text { Tax burden as } \\
\text { \% GDP }\end{array}$ & $\begin{array}{c}\text { Fees and user } \\
\text { charges as } \\
\% \text { GDP }\end{array}$ & $\begin{array}{c}\text { Local and re- } \\
\text { gional fees and } \\
\text { user charges as } \\
\% \text { GDP }\end{array}$ & $\begin{array}{l}\text { Share of local } \\
\text { and state taxes } \\
\text { in total taxes }\end{array}$ \\
\hline Australia & 28.38 & 2.61 & 1.61 & 6.91 \\
\hline Austria & 42.09 & 3.87 & 2.01 & 4.78 \\
\hline Belgium & 43.52 & 2.33 & 1.87 & 4.29 \\
\hline Canada & 33.09 & 4.15 & 3.53 & 10.74 \\
\hline Czech Republic & 33.51 & 3.47 & 1.90 & 5.68 \\
\hline Denmark & 46.26 & 3.60 & 1.83 & 3.96 \\
\hline Estonia & 32.32 & 2.95 & 0.80 & 2.48 \\
\hline Finland & 43.16 & 6.24 & 4.06 & 9.43 \\
\hline France & 43.40 & 3.66 & 1.60 & 3.70 \\
\hline Germany & 35.57 & 2.88 & 2.33 & 6.55 \\
\hline Greece & 32.44 & 2.80 & 0.24 & 0.73 \\
\hline Hungary & 38.09 & 3.17 & 1.13 & 2.96 \\
\hline Italy & 41.26 & 2.01 & 1.49 & 3.62 \\
\hline Latvia & 28.79 & 2.81 & 0.83 & 2.89 \\
\hline Netherlands & 36.13 & 3.53 & 2.14 & 5.87 \\
\hline Norway & 41.18 & 3.59 & 2.01 & 4.89 \\
\hline Poland & 33.38 & 3.36 & 1.46 & 4.37 \\
\hline Portugal & 31.46 & 3.36 & 1.06 & 3.39 \\
\hline Slovak Republic & 32.15 & 2.85 & 0.80 & 2.55 \\
\hline Slovenia & 36.92 & 3.55 & 1.29 & 3.51 \\
\hline Spain & 32.91 & 1.91 & 1.40 & 4.25 \\
\hline Sweden & 45.33 & 4.37 & 2.84 & 6.25 \\
\hline Switzerland & 26.74 & 3.82 & 3.32 & 12.52 \\
\hline United Kingdom & 31.91 & 2.09 & 1.35 & 4.19 \\
\hline United States & 25.86 & 4.05 & 3.76 & 14.60 \\
\hline
\end{tabular}

Source: own calculations on a basis of OECD Fiscal Decentralisation Database. 
to the economic situation of a country. This phenomenon is evident in the case of consumption taxes and income taxes. These taxes represent $55 \%$ of tax revenue in Germany to $86 \%$ in Denmark, thus a major part of public revenue largely depends on the economic situation. In a situation where the economic situation of the country is deteriorating, public expenditure remains unchanged, and can even be assumed to rise. On the one hand, there is therefore strong pressure to increase the public sector deficit and the financing of public spending increasingly depends on issuing public debt. On the other hand, the excessive deficit procedure in the case of EU member states and other internal constraints, not necessarily formalized (for all countries), make it necessary to maintain the deficit at the same or lower level. On average, the fees and user charges to the GDP ratio in the surveyed countries has risen by $0.18 \%$ GDP.

Fees and user charges are more often used in local government units than in central government due to the nature of the tasks performed by local government. Aside from the differences in the regulations of local governments in specific countries, this may indicate that these tasks largely relate to social services and infrastructure. This confirms the traditional view on decentralization which suggests that, where the provision of public goods provides benefits on a national scale, it is appropriate for central government to supply them, but where public goods provide localized benefits they should be supplied at the local level. In the case of such goods it is easier and more reasonable to introduce fees and user charges.

Local governments therefore principally apply the policy of increasing revenues from fees and user charges. The increase amounted on average $0.085 \%$ GDP (in countries that the ratio has risen-it was $0.50 \% \mathrm{GDP}$, and in those where it declined $-0.57 \%$ GDP). These findings do not change the fact that, while at the level of fiscal policy central governments are the beneficiaries of changes in revenues from fees and user charges, in most countries a significant part of revenues from fees as a source of financing public expenditure is collected at the local government level. This confirms that there is greater scope for introducing fees and user charges for services at the local level. Introducing charges, as previously indicated, leads to a series of economic effects, including reduction in demand, and perhaps limiting the availability of the service. It is indicated that a taxpayer may react to the introduction or increase of fees and user charges in three ways: by using fewer services, changing the place of residence (according to the Tiebout [1956] hypothesis) or by controlling spending in the political process. If, therefore, fees and user charges are treated as prices, the demand and hence revenue from user charges will be derived from wealth.

Fees and user charges typically involve receiving a return benefit from the public entity. This is usually a service, or the issuing of a specific document. According to the principle formulated by Stigler [1957], people should be able to decide on the type and level of public services they receive, while local governments operate more effectively than central government. In theory, these two facts justify a higher share of fees and user charges in local government revenues, although increased public revenue from charges occurred more frequently on a nationwide basis than at the local level. 
This makes it possible to use charges to increase the efficiency of the allocation of public funds. A user charge, as a financial category, is similar to the price of goods, and therefore, according to the theory, allocation with the use of charges should be more effective than without them. Moreover, in a situation where a service is provided by a self-financing entity, revenues from user charges enforce discipline to incur costs, as only in this way can an entity survive.

\section{Methodology and model}

In order to carry out the analysis a model that specifies the use of user charges as a source of funds for public tasks has been designed. The analysis was carried out on a panel of 26 OECD countries using data from the years 1995-2016. Data was gathered using OECD databases such as OECD Statistics and the OECD Fiscal Decentralisation Database. As mentioned, only those countries for which complete data was available were chosen for the research.

The main focus in this research is on local fees and user charges, therefore, beyond the recognition of fees as a source of public revenue (FEES), separately taken subject of fees collected at the regional or local levels (FEESLS).

The models will be used in order to verify following hypotheses:

1. Fees and user charges revenues are dependent on fiscal decentralization.

2. Fees and user charges are positively affected public expenditure.

3. Fees and user charges depend on the wealth of a society.

The dependent variable are respectively:

- Log.FEES: Log of public revenues from fees and user charges in mio USD (PPP);

- Log.FEESLS: Log of public revenues for local and regional government from fees and user charges in mio USD (PPP).

Independent variables in the two models are:

- TAX: tax burden as a percentage of GDP;

- GDPCAP: GDP per capita in current prices, USD PPP;

- DECEN: share of local and state taxes in total taxes;

- Log.EXP: log of general government expenditures in mio USD PPP;

- Log.EXPLS: log of local and state government expenditures in USD PPP.

TAX describes the share of tax revenues in the GDP. Taxes are the most obvious source of public revenue, but at the same time a number of researchers show that for various reasons, followed by a retreat from them, but rather the search for non-tax revenues, such as user fees. The role of the fees is different from other public revenues due to the link between the payer and the beneficiary of the public service. A general trend binds, however, with the growing importance of fees as public revenue so the expected direction is a negative correlation between the share of tax revenues and fees.

Variable DECEN describes the degree of decentralization of public levies (the ratio of tax revenues in the local and regional budgets to the general tax revenue). 
Usually governments, especially local services having the character of social goods or excludable public goods. In the case of goods these much more often than in the case of "ordinary" public goods, it is possible to introduce payment. This suggests that a higher degree of decentralization should be associated with higher revenues from fees.

The EXP variable in the model determines the overall amount of public expenditure, while the decentralized model — spending of regional governments and local authorities. It allows determining the relationship between fees and expenditures. It is true that there is disagreement on this issue, as on the one hand, you can find a study that showed a positive correlation between fees and public spending, as well as those in which the relationship is negative. In the second model, the variable EXPLS covers only local and regional expenses (without central or federal).

Table 3

Expected direction independent variables' impact

\begin{tabular}{|c|c|c|}
\hline $\begin{array}{c}\text { Independent } \\
\text { variable }\end{array}$ & $\begin{array}{l}\text { Expected } \\
\text { direction }\end{array}$ & Research \\
\hline TAX & negative & $\begin{array}{l}\text { Both, internationally [Börge, 2000], and in Poland [Będzieszak, } \\
\text { 2013], the trend of a growing share of user charges in local rev- } \\
\text { enues is observable. } \\
\text { Those municipalities, which don't charge for their services yet, will } \\
\text { do so in the future [Downing, 1992]. } \\
\text { Implementation of user charges is motivated by limiting taxes and } \\
\text { expenditures [Sun, Jung, 2012]. }\end{array}$ \\
\hline GDPCAP & positive & $\begin{array}{l}\text { User charges for kindergartens rise simultaneously with household } \\
\text { income but decrease with municipal revenues. User charges for el- } \\
\text { derly and disabled care rise simultaneously with household income } \\
\text { [Aaberge, Langøren, 2006]. } \\
\text { Revenue variation is dependent on many factors, among which, the } \\
\text { most important is household income [Carroll, 2009]. }\end{array}$ \\
\hline DECEN & positive & $\begin{array}{l}\text { According to benefit model of local government, municipalities } \\
\text { should whenever possible deliver services for which citizens can } \\
\text { pay [Kitchen, Slack, 2003]. }\end{array}$ \\
\hline EXP & negative & \multirow[b]{2}{*}{$\begin{array}{l}\text { Implementation of user charges is motivated by limiting taxes and } \\
\text { expenditures [Sun, Jung, 2012]. } \\
\text { Expenditures adapt, among others, to short-term changes in taxes } \\
\text { and other sources of revenues [Westerlund et al., 2011]. } \\
\text { Links between payer and user even if is not justified by law can } \\
\text { lead to the rationalization of expenditures [Börge, 1995]. } \\
\text { User charges should motivate the economical use of resources } \\
\text { [Fitch, 1957]. } \\
\text { In some cases, user fees offset expenditures to a significant degree. } \\
\text { In other areas expenditures are substantially higher than revenues, } \\
\text { but charges are increasing [Bartle et al., 2003]. }\end{array}$} \\
\hline EXPLS & negative & \\
\hline
\end{tabular}

Source: own study. 
In table 4 descriptive statistics for variables have been presented. Detailed data about the mean values of variables have been presented in the boxes.

The most diversified variable of the analysed are dependent variables - the coefficient of variation in their case was $290.79 \%$ for FEES and 315.84\% for FEESLS respectively. The least diversified were TAX $-17.18 \%$ and GDPCAP $-39.91 \%$.

In the research period, FEES and FEESLS, constantly grew and the growth rate between 1995 and 2016 was 2.6. There has been almost no difference in the growth rate between those two variables. It has to pointed out that the year to year growth rate in the case of those variables was at its highest point in 2006 and has been dropping ever since - to ca. 3\%. Quite a similar situation can be observed in the case of EXP and EXPLS. The growth rate in the whole period was 2.27 and 2.47 respectively, it was the highest in the 2000s and then it dropped to ca. $3 \%$.

The decentralization of public revenues DECEN was higher at the end of the research period $(16.77 \%)$ than at the beginning $(15.7 \%)$, but it has been decreasing over the last few years. What is interesting is that there are no bigger changes in the tax revenues in the GDP (TAX).

Table 4

Descriptive statistics for variables

\begin{tabular}{|l|c|c|c|c|c|}
\hline \multicolumn{1}{|c|}{ Variable } & Mean & Std. Dev. & Median & Minimum & Maximum \\
\hline FEES & 36316 & 105600 & 11094 & 214.1 & 773800 \\
\hline FEESLS & 31103 & 98236 & 6805 & 64.37 & 723700 \\
\hline TAX & 35.56 & 6.11 & 34.70 & 23.02 & 49.98 \\
\hline GDPCAP & 30742 & 12268 & 29371 & 5491 & 70756 \\
\hline DECEN & 15.32 & 13.17 & 11.34 & 0.76 & 50.63 \\
\hline EXP & 480000 & 1015000 & 146500 & 3690 & 7160000 \\
\hline EXPLS & 200400 & 494000 & 56112 & 916.9 & 3537000 \\
\hline
\end{tabular}

Source: own calculations on a basis of OECD data.

Table 5

Correlation matrix for variables $\mathrm{N}=572$

\begin{tabular}{|c|c|c|c|c|c|}
\hline TAX & GDPCAP & DECEN & Log.EXP & Log.EXPLS & \\
\hline 1.0000 & 0.0576 & -0.0200 & 0.0194 & 0.0539 & TAX \\
\hline \multirow{2}{*}{1.0000} & 0.3733 & 0.4818 & 0.5301 & GDPCAP \\
\cline { 3 - 6 } & 1.0000 & 0.3788 & 0.5541 & DECEN \\
\cline { 3 - 6 } & & 1.0000 & 0.9534 & Log.EXP \\
\cline { 3 - 6 } & & & 1.0000 & Log.EXPLS \\
\cline { 3 - 6 }
\end{tabular}

Source: own calculations on a basis of OECD data. 


\section{Results of regression}

The results of regression in the first model - for the whole public sector have been presented in table 6 and the second - for local and regional government in table 7 .

Table 6

Coefficients: model 1

\begin{tabular}{|c|c|c|c|c|}
\hline Coefficient & \multicolumn{2}{|c|}{ OLS } & \multicolumn{2}{|c|}{ Fixed-Effect } \\
\hline TAX & $\begin{array}{l}-0.0092 \\
(0.0017)\end{array}$ & $* * *$ & $\begin{array}{l}-0.0076 \\
(0.0038)\end{array}$ & $* *$ \\
\hline GDPCAP & $\begin{array}{c}7.07 \mathrm{E}-06 \\
(1.00 \mathrm{E}-06)\end{array}$ & $* * *$ & $\begin{array}{r}3.4775 \mathrm{E}-06 \\
(1.8188 \mathrm{E}-06)\end{array}$ & $*$ \\
\hline DECEN & $\begin{array}{c}0.0101 \\
(0.0009)\end{array}$ & $* * *$ & $\begin{array}{c}0.0060 \\
(0.0035)\end{array}$ & $*$ \\
\hline Log.EXP & $\begin{array}{c}0.9263 \\
(0.0084)\end{array}$ & $* * *$ & $\begin{array}{c}1.036 \\
(0.0467)\end{array}$ & $* * *$ \\
\hline CONST & $\begin{array}{l}-1.8137 \\
(0.1077) \\
\end{array}$ & $* * *$ & $\begin{array}{l}-3.0263 \\
(0.5165)\end{array}$ & $* * *$ \\
\hline R2 & \multicolumn{2}{|c|}{0.9717} & \multicolumn{2}{|c|}{0.8892} \\
\hline
\end{tabular}

Source: own calculations on a basis of OECD data.

Table 7

Coefficients: model 2

\begin{tabular}{|l|c|c|c|c|}
\hline \multicolumn{1}{|c|}{ Coefficient } & \multicolumn{2}{|c|}{ OLS } & \multicolumn{2}{c|}{ Fixed-Effect } \\
\hline TAX & -0.0122 & $* * *$ & -0.0034 & \\
& $(0.0024)$ & & $0.0044)$ & \\
\hline GDPCAP & $7.50 \mathrm{E}-06$ & $* * *$ & $1.023 \mathrm{E}-05$ & $* * *$ \\
& $(1.19 \mathrm{E}-06)$ & & $(1.4035 \mathrm{E}-06)$ & \\
\hline DECEN & -0.0021 & & 0.0091 & $* *$ \\
& $(0.0015)$ & & $(0.0036)$ & $* * *$ \\
\hline Log.EXPLS & 0.9052 & $* * *$ & 0.7680 & $(0.0336)$ \\
& $(0.0013)$ & & 0.0282 & \\
\hline CONST & -2.416 & $* * *$ & $0.3637)$ & \\
& $(0.1270)$ & & \multicolumn{2}{c|}{0.8415} \\
\hline R2 & \multicolumn{2}{|c|}{0.9640} & & \\
\hline
\end{tabular}

Source: own calculations on a basis of OECD data.

In both models, fees and user charges are negatively associated with the tax revenues TAX. The results are in line with the assumption that, i.e. countries had to seek additional revenues at the expense of tax revenue. This phenomenon occurs both, in the consolidated and local model. 
This is directly linked to the dependency of revenue from fees and user charges FEES from expenditure EXP, EXPLS. In both cases, i.e. the centralized and decentralized model, it has a positive direction, which suggests that countries in the situation of increasing spending - increase fees and user charges. This explanation is suitable for the case of changes in public tasks. In any case, the task financed from public funds must have a legal basis, the basis of which spending shall be made. If a new task or a task where the scope is increased and associated with incurring charges by the user, it is natural regulation that will contain such provisions and, therefore, the revenue from fees will increase. In the situation, if the new job is supplied free of charge, the increased revenue from the fees will be associated with the search for new sources of revenue. In the literature one can find different, often contradictory research results regarding the fiscal illusion, but with such a situation, one can speak here.

The statistically insignificant variable in the second model is DECEN (OLS method). It was placed in the model in order to keep an analogy in relation to the first model, and considering that decentralization is an important factor in determining the amount of fees and user charges. According to the second assumption in most cases, paid services are implemented at the local level rather than central, so a higher level of decentralization should be associated with relatively higher fees and user charges revenue. This logic is correct for the measurement of revenues from fees and user charges at the consolidated level, but it does not matter to the local government, because decentralization leads to the reallocation of a particular source of public funds from the state budget to local budgets. At the consolidated level, which is presented in Model 1 fees and user charges revenues for the whole public sector have been included. This fact confirms the significance of this variable in the model, but as it turns out in the decentralized model it is insignificant. The direction of the relationship is as expected.

\section{Revenue policy changes}

In order to confirm the changes made in the policies of countries, an additional test has been conducted. In this method changes in revenues per capita will be shown. Each country is characterized by two variables: fees per capita and tax revenues per capita. The combination of these two features allows determining the applicable revenue policy on fees. Countries can therefore apply the following 4 types of revenue policy:

- High revenues from fees and a low tax revenues policy,

- High revenues from fees and a high tax revenues policy,

- Low revenues from fees and a low tax revenues policy,

- Low revenues from fees and a high tax revenues policy.

The method adopted the normalization of indicators of efficiency and effectiveness is based on the concept of benchmarking, i.e. a comparison with the best. A question that needs to be answered is - whether the country implements the policy of increasing revenues from fees to a greater extent than in the case of tax revenues? If the country uses fees as an instrument of revenue gathering, then 
comparing to other countries it has high fees per capita ratio (policy 1 and 2), but if not-it has a low ratio (policy 3 and 4 ).

For the purpose of carrying out the analysis the normalization quotient mapping, according to the following formula, has been made:

$$
\mathrm{FUC}=\frac{\text { fees.user.charges }_{\mathrm{i}}}{\text { MAX (fees.user.charges) }}
$$

where:

fees.user.charges: fees and user charges per capita in i-country

MAX (fees.user.charges): maximum fees and user charges per capita for countries, per annum.

Analogous index normalization for TAX (tax revenues) has been made with the use of the formula:

$$
\operatorname{TAX}=\frac{\operatorname{tax}_{\mathrm{i}}}{\operatorname{MAX}(\operatorname{tax})}
$$

where:

$\operatorname{tax}_{\mathrm{i}}$ : tax revenues per capita in i-country

MAX (tax): maximum tax revenues per capita for countries, per annum.

The borderline for qualifying certain country to "low" or "high" group is median of the indexes, ie. if FUCti $>$ median (FUCt), then the feature is "high", etc.

Given that the revenues from the fees are not the dominant source of operating own-source revenues, it must be held that the policy of a high operating ownsource revenues policy is consistent with the theory of Leviathan. The results of analysis has been presented in table 8 .

Table 8

Number of countries with different types of fees and user charges policies

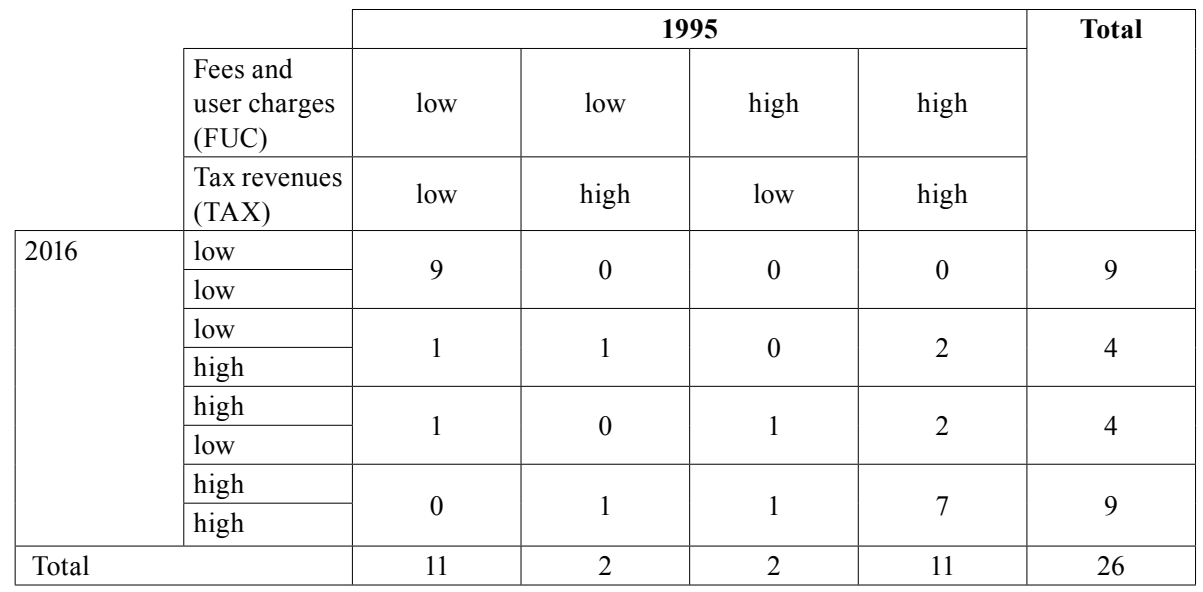

Source: own calculations on a basis of OECD data. 
There are two main conclusions on the results. First, the distribution of countries between main group is quite equal. It should be noted that the largest group of countries is the one with low taxes and low fees per capita (table 8). The second conclusion is that countries generally don't change their policy radicallyon average there are no significant changes in a number of countries in the four groups, which means that countries on average have the same policy on fees and user charges.

\section{Conclusions/discussion}

The fees and user charges in many countries form an increasingly significant part of public revenues. This is due, on the one hand, to insufficient tax revenue, and on the other to additional effects associated with the introduction of fees and user charges. Public finance theory indicates that higher fees and user charges services should lead to lower spending on these services. This is mainly justified by demand factors. The increase in prices for the service leads to a decrease in the level of demand due to reduced interest in consumption or the exclusion of certain consumers. Empirical studies confirm this hypothesis, although it is worth pointing out that there are three possible scenarios: changes occur in parallel, the change in the level of charges is the cause and effect of change in spending, and the reverse.

Fees and user charges are therefore not a major source of funding for services. As shown in studies, the level of wealth of a society is very important if the charges are treated as a price for the service, both in terms of the level of demand, but also affordability. Fees and user charges also serve a substitute for traditional tax revenues. The research has shown that there is a positive relationship between fees and user charges and expenditures, while negative in the case of tax revenues. This suggests that countries having higher expenditures and lower tax revenues look for other sources of public revenues.

It is in line with expectations and easy to justify that there is no statistically significant relation between the dependent variable and decentralization in the local model and significant - in the consolidated model. The positive coefficient suggests that the higher degree of decentralization leads to higher revenues from fees and user charges. 
Annex 1

Cross-country data on means of variables

\begin{tabular}{|c|c|c|c|c|c|c|c|}
\hline $\begin{array}{l}\text { Country/ } \\
\text { variable }\end{array}$ & FEES & FEESLS & TAX & $\begin{array}{l}\text { GDP. } \\
\text { CAP }\end{array}$ & DECEN & EXP & EXPLS \\
\hline Australia & 22317 & 15295 & 28.38 & 36191 & 19.73 & 276555 & 126531 \\
\hline Austria & 12064 & 6006 & 42.09 & 36809 & 4.89 & 157817 & 53541 \\
\hline Belgium & 8874 & 7106 & 43.52 & 34440 & 9.27 & 192114 & 82141 \\
\hline Canada & 49362 & 42272 & 33.09 & 35494 & 47.84 & 486767 & 358873 \\
\hline Czech Republic & 8342 & 4423 & 33.51 & 23152 & 1.06 & 102946 & 28246 \\
\hline Denmark & 7204 & 3590 & 46.26 & 36153 & 29.09 & 107543 & 66795 \\
\hline Estonia & 690 & 198 & 32.32 & 17670 & 1.24 & 8960 & 2270 \\
\hline Finland & 11166 & 7367 & 43.16 & 33001 & 22.27 & 92188 & 35899 \\
\hline France & 73866 & 32771 & 43.40 & 31537 & 11.65 & 1098409 & 217503 \\
\hline Germany & 83747 & 67038 & 35.57 & 34572 & 29.89 & 1312954 & 595322 \\
\hline Greece & 7433 & 642 & 32.44 & 24041 & 1.46 & 130081 & 9301 \\
\hline Hungary & 5608 & 1868 & 38.09 & 17651 & 5.56 & 87961 & 18954 \\
\hline Ireland & 3819 & 1668 & 28.73 & 40007 & 2.53 & 64583 & 11950 \\
\hline Italy & 36839 & 27394 & 41.26 & 31185 & 14.12 & 892704 & 268088 \\
\hline Latvia & 959 & 270 & 28.79 & 14658 & 18.22 & 11853 & 3167 \\
\hline Netherlands & 22081 & 13259 & 36.13 & 38764 & 3.56 & 285724 & 92970 \\
\hline Norway & 7943 & 4419 & 41.18 & 47426 & 14.87 & 103244 & 34557 \\
\hline Poland & 19105 & 8572 & 33.38 & 16266 & 11.53 & 273404 & 83068 \\
\hline Portugal & 8151 & 2536 & 31.46 & 22937 & 6.50 & 111283 & 15182 \\
\hline Slovak Republic & 3243 & 900 & 32.15 & 18847 & 2.13 & 43563 & 6132 \\
\hline Slovenia & 1735 & 629 & 36.92 & 23769 & 8.52 & 23315 & 4241 \\
\hline Spain & 23728 & 17613 & 32.91 & 27238 & 20.72 & 511101 & 254756 \\
\hline Sweden & 14319 & 9183 & 45.33 & 36237 & 33.09 & 176061 & 79854 \\
\hline Switzerland & 13603 & 11789 & 26.74 & 45604 & 39.97 & 117336 & 71558 \\
\hline
\end{tabular}

Source: own calculations on a basis of OECD data. 
Annex 2

Time series data on means of variables

\begin{tabular}{|l|l|l|l|l|l|l|l|}
\hline $\begin{array}{c}\text { Year/ } \\
\text { variable }\end{array}$ & FEES & FEESLS & TAX & GDP.CAP & DECEN & EXP & EXPLS \\
\hline 1995 & 22252 & 17427 & 35.98 & 18484 & 14.44 & 299088 & 116181 \\
\hline 1996 & 23312 & 18312 & 36.35 & 19282 & 14.53 & 302804 & 120506 \\
\hline 1997 & 24163 & 19129 & 36.12 & 20341 & 14.30 & 309234 & 123836 \\
\hline 1998 & 25205 & 20014 & 36.29 & 21280 & 14.56 & 319486 & 130040 \\
\hline 1999 & 26403 & 21166 & 36.46 & 22261 & 14.55 & 331721 & 137909 \\
\hline 2000 & 28145 & 22528 & 36.28 & 23973 & 14.33 & 349019 & 146999 \\
\hline 2001 & 30174 & 24104 & 35.56 & 25022 & 14.71 & 370693 & 158183 \\
\hline 2002 & 31870 & 25486 & 35.31 & 26131 & 15.05 & 392420 & 168022 \\
\hline 2003 & 33254 & 26767 & 35.13 & 26885 & 15.23 & 411247 & 176141 \\
\hline 2004 & 35386 & 28275 & 35.12 & 28439 & 15.36 & 430123 & 184734 \\
\hline 2005 & 37472 & 29637 & 35.39 & 29847 & 15.27 & 453527 & 193345 \\
\hline 2006 & 40137 & 31798 & 35.47 & 32445 & 15.34 & 481861 & 205868 \\
\hline 2007 & 42433 & 33560 & 35.57 & 34445 & 15.26 & 508529 & 218279 \\
\hline 2008 & 44703 & 35154 & 34.97 & 35949 & 15.50 & 549587 & 231874 \\
\hline 2009 & 46871 & 36773 & 34.47 & 34759 & 16.10 & 584693 & 244746 \\
\hline 2010 & 48822 & 38272 & 34.46 & 35859 & 15.97 & 604609 & 249535 \\
\hline 2011 & 50677 & 39673 & 34.74 & 37449 & 15.93 & 613319 & 252585 \\
\hline 2012 & 51653 & 40552 & 35.25 & 38188 & 16.15 & 621217 & 255561 \\
\hline 2013 & 53121 & 42021 & 35.66 & 39625 & 16.04 & 635579 & 261500 \\
\hline 2014 & 54819 & 43315 & 35.81 & 40628 & 16.00 & 648339 & 268598 \\
\hline 2015 & 56178 & 44458 & 35.83 & 41953 & 16.14 & 662254 & 277658 \\
\hline 2016 & 57897 & 45849 & 36.13 & 43080 & 16.30 & 681425 & 286795 \\
\hline
\end{tabular}

Source: own calculations on a basis of OECD data.

\section{References}

Aaberge R., Langøren A. (2006), Measuring the benefits from public services: The effects of local government spending on the distribution of income in Norway, Review of Income and Wealth Series, 52, 1.

Bartle J., Ebdon C., Krane D. (2003), Beyond the property tax: Local government revenue diversification, Journal of Public Budgeting, Accounting \& Financial Management, 15, 4.

Będzieszak M. (2013), Fees and user charges in large Polish cities, Studia Regionalne i Lokalne, 4, 54. 
Bierhanzl E. J., Downing P. B. (1998), User charges and bureaucratic inefficiency, Atlantic Economic Journal, 26, 2.

Bird R. M., Slack N. E. (1993), Urban Public Finance in Canada, $2^{\text {nd }}$ ed., John Wiley and Sons, Toronto.

Börge L. E. (1995), Economic and political determinants of fee income in Norwegian local governments, Public Choice, 83.

Börge L. E. (2000), Charging for public services: The case of utilities in Norwegian local governments, Regional Science and Urban Economics, 30.

Bös D. (1984), Income taxation, public sector pricing and redistribution, The Scandinavian Journal of Economics, 86, 2.

Carroll D. (2009), Diversifying municipal government revenue structures: Fiscal illusion or instability? Public Budgeting \& Finance (Spring).

Cremer H., Marchand M., Pestieau P. (1997), Investment in local public services: Nash equilibrium and social optimum, Journal of Public Economics, 65.

Downing P. B. (1992), The revenue potential of user charges in municipal finance, Public Finance Review, 20, 4.

Feld L. P., Kirchgässner G., Schaltegger C. A. (2003), Decentralized taxation and the size of government: Evidence from Swiss state and local governments, CESifo Working Paper No. 1087.

Feldstein S. (1972), Equity and efficiency in public sector pricing: The optimal two-part tariff, The Quarterly Journal of Economics, 86, 2.

Fitch L. C. (1957), Metropolitan financial problems, Annals of the American Academy of Political and Social Science, 314.

Fuest C., Kolmar M. (2007), A theory of user-fee competition, Journal of Public Economics, 91.

Huber B., Runkel M. (2009), Tax competition, excludable public goods, and user charges, International Tax and Public Finance, 16.

Kitchen H. M., Slack E. (2003), New finance options for municipal governments, Canadian Tax Journal / Revue Fiscale Canadienne, 51, 6.

Nallathiga R. (2009), User charge pricing for municipal services: Principles, fixation, process and guidelines, CGG Working Paper, Centre for Good Governance (CGG), Hyderabad.

Sepehri A., Chernomasa R. (2001), Are user charges efficiency- and equity-enhancing? A critical review of economic literature with particular reference to experience from developing countries, Journal of International Development, 13, 2.

Stigler G. (1957), The tenable range of functions of local government [in:] Federal Expenditure Policy for Economic Growth and Stability, Joint Economic Committee, Subcommittee on Fiscal Policy, U.S. Congress, Washington.

Sun R., Jung C. (2012), Does user-charge financing reduce expenditure levels for the charge-financed services? The American Review of Public Administration, 42, 2.

Swope K. J., Janeba E. (2005), Taxes or fees? The political economy of providing excludable public goods, Journal of Public Economic Theory, 7, 3.

Tiebout C. M. (1956), A pure theory of local expenditures, The Journal of Political Econo$m y, 64,5$.

Wagner R. E. (1976), Revenue structure, fiscal illusion and budgetary choice, Public Choice, 25.

Westerlund J., Mahdavi S., Firoozi F. (2011), The tax-spending nexus: Evidence from a panel of US state-local governments, Economic Modelling, 28. 